\title{
The 2009 recipient of the Brady Medal: Dr Thomas M. Cronin
}

\author{
DAVID J. HORNE ${ }^{1} \&$ ALAN LORD ${ }^{2, *}$ \\ ${ }^{1}$ School of Geography, Queen Mary University of London, Mile End Road, London E1 4NS, UK and Department of Zoology, \\ The Natural History Museum, Cromwell Road London SW7 5BD, UK \\ ${ }^{2}$ Senckenberg Forschungsinstitut, Senckenberganlage 25, D-60325 Frabkfurt-am-Main, Germany \\ *Corresponding author (e-mail: Alan.Lord@senckenberg.de)
}

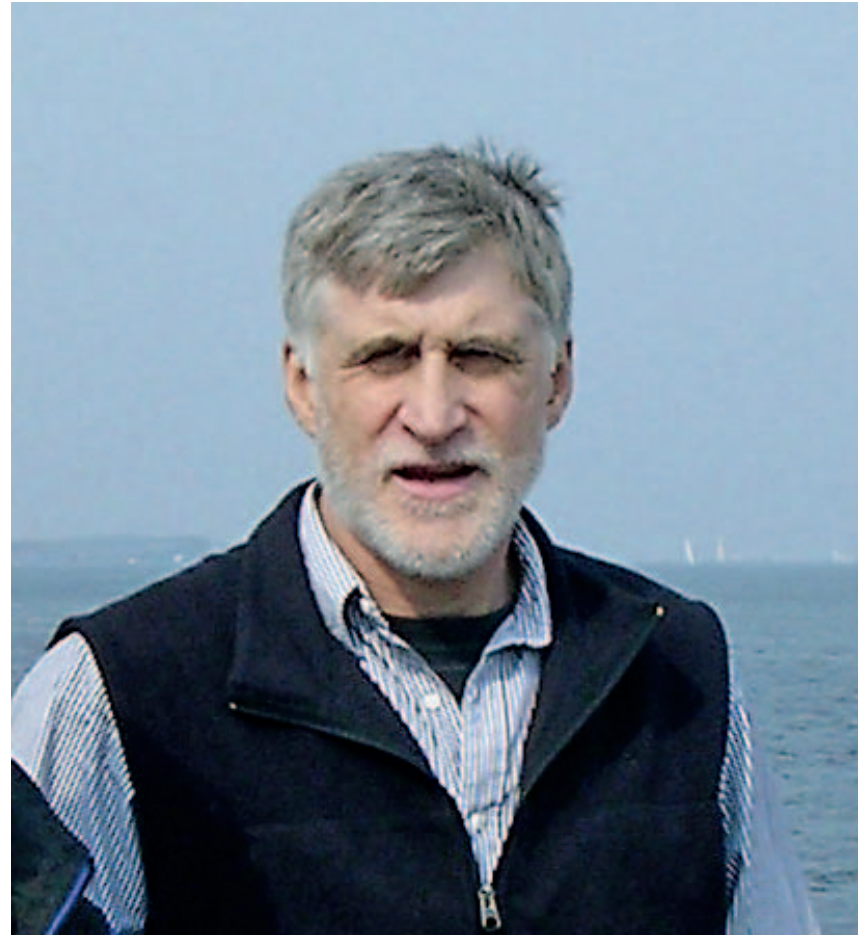

Fig. 1. Tom Cronin.

Dr Thomas Cronin is a worthy recipient of the Brady Medal, not simply for his outstanding achievements in the application of micropalaeontology to palaeoceanography, palaeoclimatology and evolutionary studies but because, like the Brady brothers, he has worked on both ostracods and foraminifera, fossil and living.

Tom Cronin was born in 1950 in the Bronx, New York City, USA and first became interested in geology when attending a freshman general course at Colgate University taught by Bob Linsley and Jim McClelland - in Tom's words: 'two great educators'. He graduated with a BA in Geology from Colgate in 1972 and then carried out postgraduate work at Harvard University leading to a MA (1974) and PhD (1977) in Geology. After graduation he joined the US Geological Survey and is currently a senior scientist with the Eastern Geology and Climate Science Center, US Geological Survey in Reston, Virginia. There his present role is Project Chief for the 'Abrupt Climate Change: Eastern US' project and he also contributes to the 'South Florida Ecosystem Project'.

Tom's doctoral work concerned both foraminifera and ostracods of the Pleistocene of the north-eastern seaboard of North America, but it is as an ostracod worker that he is best known, especially for deep sea fossil and living faunas. His publications portray a developing pattern of research interest and achievement from a relatively classical doctoral treatment of shallow marine Pleistocene ostracods and foraminifera and their environmental significance, via early marine palaeoclimate reconstruction work in the Neogene-Quaternary of the US eastern seaboard, to the innovative interpretation of deep sea palaeoceanographic parameters using ostracods and other proxies. The following brief and selective review should serve to give a flavour of Tom's outstanding scientific contributions over the past three and half decades as witnessed by a record of more than 160 publications.

At the end of the last glaciation, as the Laurentide Ice Sheet retreated, marine waters from the Atlantic inundated the isostatically depressed region of the St Lawrence lowlands to form the Champlain Sea. Tom Cronin's PhD research used ostracods and foraminifera to elucidate the complex salinity and temperature history of this inland sea, reflecting the interplay of postglacial climatic warming, eustatic sea-level rise and isostatic uplift, which he expounded in a series of publications (Cronin, 1976a, 1976b, 1977a, 1977b, 1979a, 1979b, 1981). Subsequently, increasing attention to freshwater forcing by meltwater pulses as a cause of abrupt changes in North Atlantic thermohaline circulation and climate led to a renewed interest in the salinity record of the Champlain Sea. Using benthonic foraminifera and ostracods as palaeosalinity proxies, Cronin et al. (2008a) determined that a sharp decrease in Champlain Sea salinity around $11.4-11.2 \mathrm{ka}$ could best be explained as the result of a rapid influx of freshwater from glacial Lake Algonquin, coincident with the Preboreal Oscillation, a climatic cooling episode.

Tom's contributions to the documentation of Cenozoic to Recent marine ostracod faunas from many parts of the world have advanced our knowledge and understanding of the distribution of ostracod taxa in the oceans and paved the way for applications in palaeoceanography, palaeoclimatology and evolutionary studies. Examples include descriptions and applications of ostracod faunas from the Eocene of Egypt (Cronin \& Khalifa, 1979) and Atlantic DSDP sites (Cronin \& ComptonGooding, 1987), the Neogene of Enewetak Atoll (Cronin et al., 1991) and Iceland (Cronin, 1991), the Plio-Pleistocene of Japan (Cronin \& Ikeya, 1987; Ikeya \& Cronin, 1993), the Quaternary of the Arctic (Cronin et al., 1994; Jones et al., 1999; Cronin et al., 2008b) and the Holocene of the Black Sea (Ivanova et al., 2007). In the Arctic, Cronin et al. (1994) showed the species composition of ostracod assemblages to be related to the characteristics of water masses such as Arctic Ocean Deep Water and Greenland Sea Deep Water, and demonstrated their utility as proxies for circulation changes in the Late Pleistocene and Holocene. A recent investigation of deep North Atlantic ostracod faunas over the past 20,000 years revealed major collapses of benthonic communities coincident with abrupt 
changes in deep-water circulation, probably linked to changes in surface productivity and demonstrating the sensitivity of deepsea ecosystems to benthonic habitat disturbance driven by climate change (Yasuhara et al., 2008)

A significant proportion of Tom's work, in collaboration with Harry Dowsett, Gary Dwyer and others, has addressed Neogene to Recent climate change, one focus being the reconstruction of the globally warm mid-Pliocene ocean in order to furnish data for climate modelling of the causes of Pliocene and future warmth. A benchmark paper in Science (Dwyer et al., 1995) established the utility of $\mathrm{Mg} / \mathrm{Ca}$ ratios of ostracod shells as a proxy for deep-ocean bottom-water temperatures (adapting a method originally developed in the context of nonmarine ostracods) and paved the way for innovative investigations and interpretations of Pliocene, Pleistocene and Holocene marine faunas (e.g., Cronin et al., 2000, 2003, 2005, 2010a). A Nature paper (Cronin \& Raymo, 1997) showed for the first time that the diversity of deep-ocean benthos has varied on geological timescales related to glacial-interglacial cycles and ultimately linked to the 41,000 year obliquity cycle. Investigating Late Pliocene records from North Atlantic DSDP cores, they compared ostracod species diversity with ostracod $\mathrm{Mg} / \mathrm{Ca}$ ratios and foraminiferal oxygen stable isotope ratios, respectively proxies for bottom-water temperature and global ice-volume. They showed that high deep-ocean biodiversity, far from indicating long-term environmental stability as some had thought, is relatively unstable and varies dynamically with orbitally induced changes in food supply and temperature; they found the diversity of abyssal benthonic ostracods to be markedly lower in glacials than in interglacials. Ostracod taxa (e.g., Henryhowella, Bradleya and some Krithe species) inhabiting the abyssal North Atlantic during interglacials may survive glacial intervals by shifting to bathyal environments, similar to the way in which shallow marine species shift their ranges poleward or equatorward in interglacials and glacials respectively.

In the last decade concerns about the rapid melting and disappearance of Arctic sea-ice have stimulated research on past variations in ice cover in relation to climate change. The marine ostracod Acetabulastoma arcticum is unusual in living not on the sea floor but commensally on pelagic amphipods associated with sea-ice, although its shells ultimately become part of benthonic assemblages; Cronin et al. (2010b) recognised and developed its potential as a proxy for sea-ice cover, finding support for the idea that much of the Arctic was seasonally ice-free only 6,000 years ago during an early Holocene thermal maximum.

Ostracods, having the most complete and abundant fossil record of any arthropods, are an ideal group with which to study the operation of evolutionary processes on geological timescales, particularly speciation in relation to tectonic and climatic changes. Studying the Miocene to Holocene marine ostracod Hermanites transoceanica from the Pacific and Caribbean sites, Tom found morphological stability among widely separated populations on oceanic islands (possibly indicating frequent passive dispersal events), leading to the conclusion that allopatric speciation should not be assumed in cases of geographical isolation of populations (Cronin, 1988). The rather extreme isolation of populations by the formation of the Panama Isthmus in the Pliocene, separating the Caribbean from the eastern Pacific, was found to have resulted in high speciation rates for some taxa, while for others (e.g., Orionina, Puriana) the isolation of small founder populations on islands seemed to a more significant factor (Cronin, 1987; Cronin \& Schmidt, 1988; Cronin \& Ikeya, 1990).

In summary, Tom Cronin has made major contributions to micropalaeontology and to the application of microfossils to environmental interpretation from the shelf to the deep sea, to our understanding of changing oceanographical and climatic patterns and to the linkages between them. Perhaps one of the clearest indications of Tom's reputation is that he was seconded to the White House Science Office during the Clinton Administration to help with US preparation for the Kyoto Climate Treaty. The most recent benchmark in his continuing career is the 2010 publication of the excellent book: Paleoclimates: A Context for Climate Change.

\section{Manuscript received 13 October 2010 Manuscript accepted 13 October 2010}

\section{REFERENCES}

Cronin, T.M. 1976a. An Arctic foraminiferal fauna from Champlain Sea deposits in Ontario. Canadian Journal of Earth Science, 13: 16781682.

Cronin, T.M. 1976b. A preliminary report on the paleoecology of the southern part of the Champlain Sea as indicated by the benthonic foraminifera: In: Proceedings of the 1st International Symposium on Benthonic Foraminifera of Continental Margins. Maritime Sediments, Special Publication No. 1, B, 379-384.

Cronin, T.M. 1977a. Late-Wisconsin Marine Environments of the Champlain Valley (New York, Quebec). Quaternary Research, 7: 238-253.

Cronin, T.M., 1977b. Champlain Sea Foraminifera and Ostracoda: a systematic and paleoecological synthesis. Geographie Physique et Quaternaire 31: 107-122.

Cronin, T.M. 1979a. Foraminifer and ostracode species diversity in the Pleistocene Champlain Sea of the St. Lawrence Lowlands. Journal of Paleontology, 53: 233-244.

Cronin, T.M. 1979b. Late Pleistocene benthonic Foraminifera from the St. Lawrence Lowlands. Journal of Paleontology, 53: 781-814.

Cronin, T.M. 1981. Paleoclimatic implications of late Pleistocene marine ostracodes from the St. Lawrence Lowlands. Micropaleontology, 27: $384-418$.

Cronin, T.M. 1987. Evolution, paleobiogeography and systematics of Puriana: Evolution and Speciation in Ostracoda, III. Journal of Paleontology Memoir, 21, 71pp.

Cronin, T.M. 1988. Geographical isolation in marine species: Evolution and speciation in Ostracoda, I. In: Hanai, T., Ikeya, N. \& Ishizaki, K. (Eds), Evolutionary Biology of Ostracoda, its Fundamentals and Applications. Developments in Palaeontology and Stratigraphy, 11, 871-890. Elsevier, Amsterdam.

Cronin, T.M 1991. Late Neogene marine Ostracoda from Tjornes, Iceland. Journal of Paleontology, 65: 767-794.

Cronin, T.M. 2010. Paleoclimates: A Context for Climate Change. Columbia University Press, 441pp.

Cronin, T.M. \& Compton-Gooding, E.E. 1987. Cenozoic Ostracoda from DSDP Leg 95 off New Jersey (Sites 612 and 613). Initial reports of the Deep Sea Drilling Project, Leg 95, Washington, D.C., 439-451.

Cronin, T.M. \& Ikeya, N. 1987. The Omma-Manganji ostracode fauna of Japan and the zoogeography of circumpolar species. Journal of Micropaleontology, 6 (2): 65-88.

Cronin, T.M. \& Ikeya, N. 1990. Tectonic events and climatic change: Opportunities for speciation in Cenozoic marine Ostracoda. In: Ross, R.M. \& Allmon, W. (Eds), Causes of Evolution: A Paleontological Perspective, University of Chicago Press, 210-248.

Cronin, T.M. \& Khalifa, H. 1979. Middle and Late Eocene Ostracoda from Gebel El Mereir, Nile Valley, Egypt. Micropaleontology, 25: $397-411$. 
Cronin, T.M. \& Raymo, M.E. 1997. Orbital forcing of deep-sea benthic species diversity. Nature, 385: 624-627.

Cronin, T.M. \& Schmidt, N. 1988. Evolution and biogeography of Orionina in the Atlantic, Pacific and Caribbean: Evolution and speciation in Ostracoda, II. In: Hanai, T., Ikeya, N. \& Ishizaki, K. (Eds), Evolutionary Biology of Ostracoda, its Fundamentals and Applications. Developments in Palaeontology and Stratigraphy, 11, $927-$ 938. Elsevier, Amsterdam.

Cronin, T.M, Bybell, L.M, Brouwers, E.M, Gibson, T.G, Margerum, R. \& Poore, R.Z. 1991. Neogene biostratigraphy and paleoenvironments of Enewetak Atoll, equatorial Pacific Ocean. Marine Micropaleontology, 18: 101-114.

Cronin, T.M, Holtz, T.R. \& Whatley, R.C. 1994. Quaternary paleoceanography of the deep Arctic Ocean based on quantitative analysis of Ostracoda. Marine Geology, 19: 305-332.

Cronin, T.M, Dwyer, G.S, Baker, P.A, Rodriguez-Lazaro, J. \& DeMartino, D.M. 2000. Orbital and suborbital variability in deep North Atlantic bottom water temperature obtained from $\mathrm{Mg} / \mathrm{Ca}$ ratios in the ostracode Krithe. Palaeogeography, Palaeoclimatology, Palaeoecology, 162: 45-57.

Cronin, T.M, Dwyer, G.S, Kamiya, T, Schwede, S. \& Willard, D.A. 2003. Medieval warm period, Little Ice Age and 20th century temperature variability from Chesapeake Bay. Global and Planetary Change, 36: 17-29.

Cronin, T.M, Dowsett, H.J, Dwyer, G.S, Baker, P.A. \& Chandler, M.A. 2005. Mid-Pliocene deep-sea bottom-water temperatures based on ostracode Mg/Ca ratios. Marine Micropaleontology, 54: 249-261.

Cronin, T.M., Manley, P.L., Brachfeld, S., Manley, T.O., Willard, D.A., Guilbault, J.-P., Rayburn, J.A., Thunell, R. \& Berke, M. 2008a. Impacts of post-glacial lake drainage events and revised chronology of the Champlain Sea episode 139 ka. Palaeogeography, Palaeoclimatology, Palaeoecology, 262: 46-60.
Cronin, T.M., Smith, S.A., Eynaud, F., O’Regan, M. \& King, J. 2008 b. Quaternary paleoceanography of the central Arctic based on Integrated Ocean Drilling Program Arctic Coring Expedition 302 foraminiferal assemblages. Paleoceanography, 23: PA1S18.

Cronin, T.M., Hayo, K., Thunell, R.C., Dwyer, G.S., Saenger, C. \& Willard, D.A. 2010a. The Medieval Climate Anomaly and Little Ice Age in Chesapeake Bay and the North Atlantic Ocean. Palaeogeography, Palaeoclimatology, Palaeoecology, 297: 299-310.

Cronin, T.M., Gemery, L., Briggs, W.M., Jakobsson, M., Polyak, L. \& Brouwers, E.M. 2010b. Quaternary sea-ice history in the Arctic Basin based on a new ostracode sea-ice proxy. Quaternary Science Reviews, doi: 10.1016/j.quascirev.2010.05.024

Dwyer, G.S, Cronin, T.M, Baker, P.A, Raymo, M.E, Buzas, J. \& Correge, T. 1995. Late Pliocene and Quaternary bottom water temperature change in the deep North Atlantic. Science, 270: 13471351.

Ikeya, N. \& Cronin, T.M. 1993. Quantitative analysis of Ostracoda and water masses around Japan: Application to Neogene paleoceanography. Micropaleontology, 39: 263-281.

Ivanova, E, Murdmaa, I.O, Chepalyga, A.L, Cronin, T.M, Pasechnik, I.V, Levchenko, O.V, Howe, S.S, Manushkina, A.V. \& Platonova, E.A. 2007. Holocene sea-level oscillations and environmental changes on the Eastern Black Sea shelf. Palaeogeography, Palaeoclimatology, Palaeoecology, 246: 228-259.

Jones, R.LI, Whatley, R, Cronin, T.M. \& Dowsett, H.J. 1999. Reconstructing late Quaternary deep-water masses in the eastern Arctic Ocean using benthonic Ostracoda. Marine Micropaleontology, 37: 251-272.

Yasuhara, M, Cronin, T.M, deMenocal, P.B, Okahashi, H. \& Linsley, B.K. 2008. Abrupt climate change and collapse of deep-sea ecosystems. Proceedings of the National Academy of Sciences of the United States of America, 105: 1556-1560. 


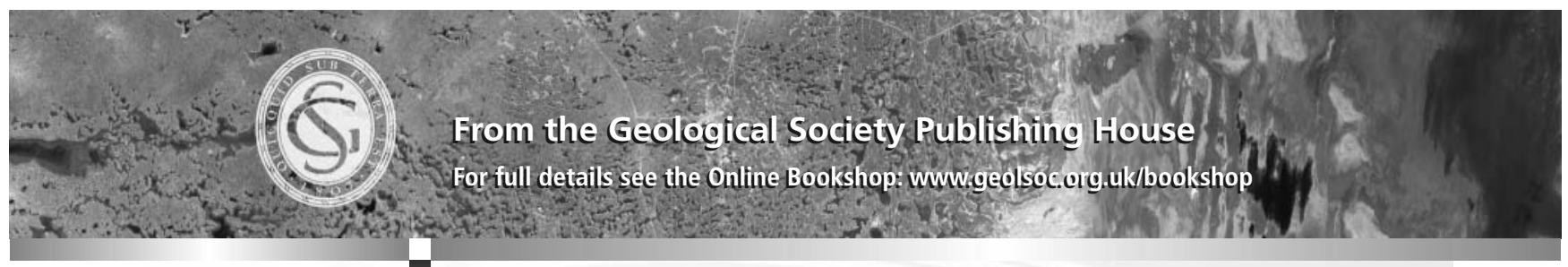

NEW

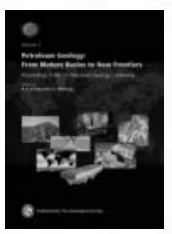

Petroleum Geology: From Mature Basins to New Frontiers - Proceedings of the 7th Petroleum Geology Conference

B. A. Vining and S. C. Pickering

Volume 1/Volume 2: The Proceedings of the 7th Petroleum Geology Conference is the seventh in a series that has become a tradition known as the 'Barbican' conferences. They started life over 35 years ago, in 1974, with a focus solely on North-West Europe, and have a reputation, both from the conferences and the accompanying proceedings volumes, of being at the forefront of petroleum geoscience; the standard reference for successive generations of petroleum geoscientists.

-ISBN: 978-1-86239-298-4 - December 2010 North-West Europe has matured as a petroleum province and, at the same time, the conference series has matured to be a truly global event. These proceedings embrace many of the world's petroleum provinces in a two-volume set. There are sections on Europe, which still provides the heart of the proceedings; Russia, the former Soviet Union and Circum-Arctic; North Africa and the Middle East; Passive Margins; and Unconventional Hydrocarbon Resources.

•Prices: GSL Energy Institute PESGB, f125.00/US\$250.00 (Cat nothe) Online bookshop code: PGC7

In addition, the three Geocontroversies debates, highly acclaimed at the conference, are included, as is a summary of the Core Workshop. A DVD complements the books and, in addition to providing electronic versions of all the papers also includes selected posters and video clips from the Virtual Field Trip session; the latter being a major success at the conference.

The proceedings volumes of this seventh conference are therefore a 'must' for every petroleum geoscientist's bookshelf.

\section{NEW}

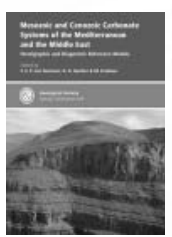

-ISBN: 978-1-86239-292-2 -May 2010 -Pages $424 \bullet$ Hardback -Prices:

List: $\mathbf{f 1 1 0 . 0 0 / U S \$ 2 2 0 . 0 0}$ GSL: $\mathbf{f 5 5 . 0 0 / U S \$ 1 1 0 . 0 0}$ Other qualifying societies: $\mathbf{f 6 6 . 0 0 / U S \$ 1 3 2 . 0 0 ~ ( C a t ~ n o ~ t b c ) ~}$ Online bookshop code: SP329

\section{NEW}

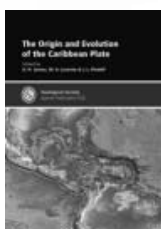

-ISBN: 978-1-86239-288-5 -January 2010

$\bullet 868$ pages $\bullet$ Hardback

List: $\mathbf{f 1 4 0 . 0 0 / U S \$ 2 8 0 . 0 0}$ GSL: $770.00 /$ US 140.00 Other $\mathbf{f}$ (0.00/US\$140.00 f84.00/US\$168.00 (Cacieties: Online bookshop code: SP328
Ond

\section{- Special Publication 329}

\section{Mesozoic and Cenozoic Carbonate Systems of the Mediterranean and the Middle East: Stratigraphic and Diagenetic Reference Models}

Edited by F. S. P. van Buchem, K. D. Gerdes and M. Esteban

This volume contains a collection of stratigraphic and diagenetic case studies of Mesozoic and Cenozoic carbonate sequences from the Tethyan realm. High levels of industry and academic interest in the region have generated numerous multi-disciplinary studies of these sequences, a selection of which are presented in this volume. The studies presented are based on both comprehensive subsurface datasets from important hydrocarbon-bearing strata of the Middle East and the excellent surface exposures in the region of interest.

The studies presented in this volume may serve as suitable starting points in the development of age and architecture specific carbonate reference models. Such models can form the basis of internally consistent models for carbonate deposition, sequence development and reservoir performance. Ideally such models, suitably scaled, will be equally applicable to academic studies, the exploration and development phases of the field life cycle and in the prediction of future reservoir performance.

\section{- Special Publication 328}

\section{The Origin and Evolution of the Caribbean Plate}

Edited by K. H. James, M. A. Lorente and J. L. Pindell

This book discusses the current state of research on the geology of the area between North and South America, with a focus on the origin of the Caribbean Plate. Prevailing understanding is that the Caribbean Plate formed in the Pacific and migrated between the Americas. According to this model, the plate comprises oceanic and volcanic arc rocks. An alternative interpretation considers that the plate formed in place and includes extended continental crust. Hybrids of these ideas also exist. The papers in this volume provide regional overviews, discussions of the origins of the Caribbean Plate, and consider aspects of local geology arranged in a circum-Caribbean tour and ending in the plate interior. They address tectonics, igneous and metamorphic geology, stratigraphy and palaeontology. The objective of this wide variety of topics is to facilitate debate.

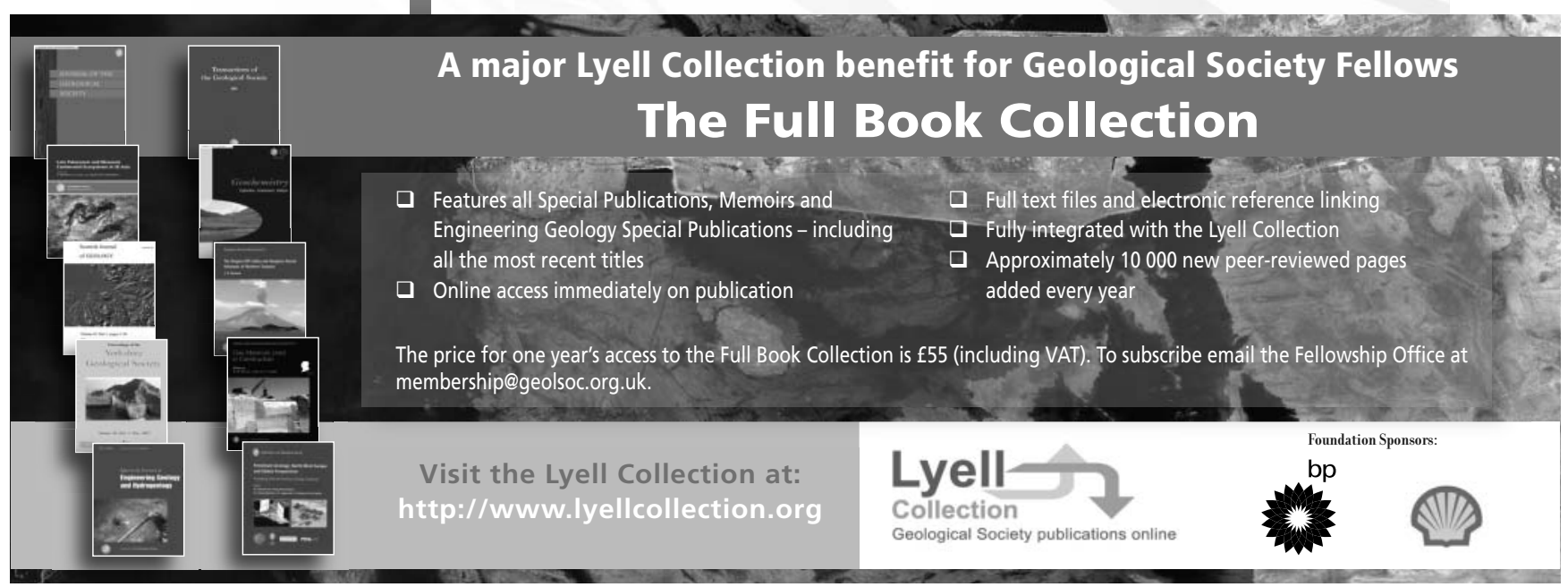

